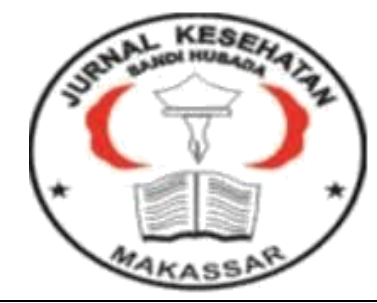

Jurnal Ilmiah Kesehatan Sandi Husada

hhttps://akper-sandikarsa.e-journal.id/JIKSH

Volume 9, Nomor 2, Desember 2020, pp 976-982

p-ISSN: 2354-6093 dan e-ISSN: 2654-4563

DOI: $10.35816 /$ jiskh.v10i2.446

\title{
Hubungan Gaya Hidup dengan Kejadian Stroke
}

Artikel Penelitian

Lifestyle Relationship with Stroke Incidence

Hartaty Hartaty ${ }^{1}$, Abdul Haris ${ }^{2}$

${ }_{12}$ Akademi Keperawatan Sandi Karsa

\section{Artikel info}

\section{Artikel history:}

Received; Agustus 2020

Revised: September 2020

Accepted; Oktober 2020

\begin{abstract}
.
Background; risky behavior leads to unbalanced consumption and smoking habits, drinking alcoholic beverages and lack of exercise. Method; a case control study with a retrospective approach. The number of respondents 30 people obtained by purposive sampling. Data analysis using univariate and bivariate. Result; statistical test showed smoking ( $p=$ $0.001)$, alcohol $(p=0.002)$, diet $(p=0.000)$, exercise $(p=0.000)$ had a relationship with the incidence of stroke. Conclusion; In stroke patients who do not regularly control treatment, the incidence of stroke will increase compared to those who regularly control medication. Nonadherence to therapy programs is a major problem in stroke survivors.

Abstrak

Latar belakang; perilaku yang berisiko menimbulkan penyakit konsumsi yang tidak seimbang dan kebiasaan merokok, minum minuman beralkohol dan kurang berolahraga. Metode; penelitian case control dengan pendekatan retrospektif. Jumlah responden 30 orang didapatkan dengan purposive sampling. Analisis data dengan univariat dan bivariat. Hasil; uji statistik menunjukkan merokok ( $p=0.001)$, Alkohol $(\mathrm{p}=0.002)$, pola makan $(\mathrm{p}=0.000)$, olahraga $(\mathrm{p}=0.000)$ terdapat hubungan dengan kejadian stroke. Kesimpulan; Pada penderita stroke yang tidak teratur melakukan kontrol berobat kejadian stroke akan meningkat dibanding dengan yang teratur melakukan kontrol berobat. Ketidakpatuhan terhadap program terapi merupakan masalah yang besar pada penderita stroke.
\end{abstract}

\section{Keywords: \\ Merokok; \\ Minum Alkohol; \\ Pola Makan; \\ Olahraga; \\ Stroke;}

Coresponden author:

Email: hartaty@gmail.com

artikel dengan akses terbuka dibawah lisensi CC BY -4.0 


\section{Pendahuluan}

Kesehatan terkadang menjadi hal yang paling utama dalam kehidupan, namun seringkali dalam kondisi sehat dan tidak ada keluhan, banyak orang justru tidak peduli dengan kesehatan mereka. Bentuk ketidak peduliannya adalah dengan gaya hidup yang tidak sesuai. Perilaku yang berisiko menimbulkan penyakit misalnya konsumsi yang tidak seimbang dan cenderung kurang atau berlebihan kebiasaan merokok, minum minuman beralkohol dan tidak melakukan aktifitas fisik seperti berolahraga. Berbicara tentang kesehatan manusia tentunya tidak dapat dilepaskan dengan penyakit yang mungkin diderita. Dari segala pola penyakit yang terjadi di Indonesia disamping masih tingginya penyakit menular, penyakit yang tidak menular dan sifatnya kronis/degeneratif juga sudah banyak diderita masyarakat (Alfiyanto \& Muflihatin, 2018).

Kurangnya olahraga atau bahkan sama sekali tidak menggerakkan tubuh untuk berolahraga bisa berdampak pada distribusi cairan limpa yang tidak lancar untuk mengalirkannya ke jaringan tubuh, sehingga sistem kekebalan tubuh pada virus dan bakteri jadi lemah. Lemahnya sistem imun tubuh ini bisa menyebabkan berbagai masalah kesehatan terutama flu, risiko kanker pada pria juga meningkat $45 \%$, dan wanita $28 \%$. Gangguan infeksi saluran pernapasan (ISPA), paru-paru bahkan sampai peningkatan penyakit jantung, stroke dan kolesterol. Dan pada perokok akan timbul plak pada pembuluh darah oleh nikotin sehingga memungkinkan arterosklerosis dan kemudian berakibat stroke. Pada pria angka kejadian stroke lebih banyak karena kecenderungan pria yang sering mengkonsumsi alkohol dan merokok(Amrina \& Muflihatin, 2017).

Permasalahan yang akan diterliti yaitu; bagaimana hubungan antara gaya hidup dengan kejadian penyakit stroke di Puskesmas Barombong Kota Makassar; bagaimanakah keeratan hubungan anatar gaya hidup dengan kejadian penyakit strok. Tujuan khusus penelitian yaitu mengidentifikasi hubungan antara merokok, alhkohol, pola makan dan aktifitas olahraga dengan kejadian penyakit stroke di Puskesmas Barombong Kota Makassar.

\section{Metode}

Jenis penelitian ini adalah penelitian case control dengan pendekatan retrospektif. Karena peneliti melakukan pengukuran pada variabel dependen terlebih dahulu, sedangkan variable independen ditelusuri secara retrospektif untuk menentukan ada tidaknya faktor (variable independen) yang berperan. Dalam penelitian ini populasi yang digunakan adalah pasien yang berkunjung ke Puskesmas Barombong Kota Makassar pada bulan JuniAgustus. Sampel adalah sebagian populasi yang diteliti atau sebagian dari jumlah karakteristik yang dimiliki oleh populasi. Analisis data yang digunakan univariat dan bivariat dengan uji statistik menggunakan SPSS.

\section{Hasil Dan Pembahasan}

Tabel 1. Distribusi responden berdasarkan umur, jenis kelamin, status, Pekerjaan, pendidikan

\begin{tabular}{lcc}
\hline Umur responden & $\begin{array}{c}\text { Frekuensi } \\
\text { (n) }\end{array}$ & $\begin{array}{c}\text { Presentase } \\
\text { (\%) }\end{array}$ \\
\hline $40-50$ tahun & 16 & 48,5 \\
\hline $51-60$ tahun & 13 & 42,4 \\
\hline$\geq 60$ tahun & 4 & 12,1 \\
\hline Total & $\mathbf{3 3}$ & $\mathbf{1 0 0 , 0}$ \\
\hline Jenis kelamin & & 42,4 \\
\hline Laki-laki & 14 & 57,6 \\
\hline Perempuan & 19 &
\end{tabular}




\begin{tabular}{lcc}
\hline Total & $\mathbf{3 3}$ & $\mathbf{1 0 0 , 0}$ \\
\hline Status & & \\
\hline Menikah & 27 & 81,8 \\
\hline Janda & 4 & 12,1 \\
\hline Duda & 2 & 6,1 \\
\hline Total & $\mathbf{3 3}$ & $\mathbf{1 0 0 , 0}$ \\
\hline Pekerjaan & & \\
\hline PNS & 2 & 6,1 \\
\hline Guru & 2 & 6,1 \\
\hline Wiraswasta & 5 & 15,2 \\
\hline Pensiunan & 3 & 9,1 \\
\hline Satpam & 2 & 6,1 \\
\hline Ibu rumah tangga & 14 & 42,4 \\
\hline Buruh & 4 & 12,1 \\
\hline Petani & 1 & 3.0 \\
\hline Total & $\mathbf{3 3}$ & $\mathbf{1 0 0 , 0}$ \\
\hline Pendidikan & & \\
\hline SD & 5 & 15,2 \\
\hline SMP & 10 & 30,3 \\
\hline SMA & 13 & 15,2 \\
\hline SI & 5 & $\mathbf{1 0 0 , 0}$ \\
\hline Total & $\mathbf{3 3}$ &
\end{tabular}

Menunjukkan jumlah responden yang berumur 40-50 tahun sebanyak 14 orang dengan presentase $(48,5 \%)$, umur 51-60 tahun sebanyak 13 orang dengan presentase $(42,4 \%)$, dan yang berumur lebih dari 60 tahun sebanyak 4 orang dengan presentase $(12,1 \%)$. Jumlah responden yang berjenis kelamin laki-laki sebanyak 14 orang dengan presentase $(42,4 \%)$ dan yang berjenis kelamin perempuan sebanyak 19 orang dengan presentase $(57,6 \%)$ total keseluruhan berjumlah 33 orang. Jumlah responden yang berstatus menikah sebanyak 27 orang dengan presentase $(81,8 \%)$, janda sebanyak 4 orang dengan presentase $(12,1 \%)$, dan duda sebanyak 2 orang dengan presentase $(6,1 \%)$ total keseluruhan berjumlah 33 orang. Jumlah responden yang bekerja sebagai PNS berjumlah 2 orang dengan presentase $(6,1 \%)$, Guru sebanyak $2(6,1 \%)$, wiraswasta sebanyak 5 orang $(15,2 \%)$, pensiunan 3 orang $(9,1 \%)$, satpam 2 orang $(6,1 \%)$, ibu rumah tangga sebanyak 14 orang $(12,1 \%)$, buruh sebanyak 4 orang $(12,1 \%)$, petani sebanyak 1 orang $(3,0 \%)$ total keseluruhan berjumlah 33 orang. Jumlah responden yang berpendidikan SD sebanyak 5 orang dengan presentase $(15,2 \%)$, SMP sebanyak 10 orang $(30,3 \%)$, SMA sebanyak 13 orang $(39,4 \%)$, SI sebanyak $5(15,2 \%)$ total keseluruhan berjumlah 33 orang.

Tabel. 2 Analisis Univariat responden berdasarkan perilaku merokok, minum alcohol, pola makan, olahraga, kejadian stroke

\begin{tabular}{lcc}
\hline \multicolumn{1}{c}{ Merokok } & Frekuensi (n) & $\begin{array}{c}\text { Presentase } \\
(\%)\end{array}$ \\
\hline Jika merokok & 16 & 48,5 \\
\hline Jika tidak merokok & 17 & 51,5 \\
\hline Total & 33 & 100,0 \\
\hline Alkohol & & \\
\hline & 13 & 39,4 \\
\hline Jika mengkonsumsi alkohol & 20 & 60,6 \\
\hline Jika tidak mengkonsumsi & & \\
\hline
\end{tabular}




\begin{tabular}{lcc}
\hline alkohol & & \\
\hline Total & 33 & 100,0 \\
\hline Pola makan & 17 & 51,5 \\
\hline Jika pola makan baik & 16 & 48,5 \\
\hline Jika pola makan tidak baik & 33 & 100,0 \\
\hline Total & 16 & 48,5 \\
\hline Olahraga & 17 & 51,5 \\
\hline Jika teratur berolahraga & 33 & 100,0 \\
\hline Jika tidak teratur olahraga & & 63,6 \\
\hline Total & 21 & 36,4 \\
\hline Stroke & & \\
\hline $\begin{array}{l}\text { Jika terdiagnosa oleh dokter } \\
\text { terkena stroke }\end{array}$ & 12 & 100,0 \\
\hline $\begin{array}{l}\text { Jika tidak terdiagnosa oleh } \\
\text { dokter terkena stroke }\end{array}$ & 33 & \\
\hline \multicolumn{1}{c}{ Total }
\end{tabular}
Sumber; Primer 2020

Berdasarkan hasil analisis data jumlah responden yang merokok sebanyak 16 orang dengan presentase $(48,4 \%)$, dan yang tidak merokok sebanyak 17 orang dengan presentase $(51,5 \%)$. Jumlah responden yang mengkonsumsi alkohol sebanyak 13 orang dengan presentase $(39,4 \%)$ Dan yang tidak mengkomsumsi alkohol sebanyak 20 orang dengan presentase $(60,6 \%)$. Jumlah responden dengan pola makan sehat sebanyak 17 orang dengan presentase $(51,5 \%)$, dan yang pola makan kurang sehat sebanyak 16 orang dengan presentase $(48,5 \%)$. Jumlah responden yang melakukan olahraga secara teratur sebanyak 16 orang dengan presentase (48,5\%), dan yang tidak teratur melakukan olahraga sebanyak 17 orang dengan presentase $(51,5 \%)$. Jumlah responden tertinggi yang terserang stroke sebanyak 21 orang dengan presentase $(63,6 \%)$ dan yang terendah sebanyak 12 orang dengan presentase $(36,4 \%)$.

Tabel 3 Analisis bivariat merokok, alcohol, pola makan, dan olahraga dengan kejadian stroke

\begin{tabular}{|c|c|c|c|c|c|c|c|}
\hline \multirow{3}{*}{$\begin{array}{l}\text { Merokok } \\
\text { Ya }\end{array}$} & \multicolumn{4}{|c|}{ Kejadian Stroke } & \multirow{2}{*}{\multicolumn{2}{|c|}{ Total }} & \multirow{2}{*}{$p$} \\
\hline & \multicolumn{2}{|c|}{ Ya } & \multicolumn{2}{|c|}{ Tidak } & & & \\
\hline & 15 & 45.5 & 1 & 3.0 & 16 & 48.5 & \multirow{3}{*}{0,001} \\
\hline Tidak & 6 & 18.2 & 11 & $\begin{array}{c}33 . \\
3\end{array}$ & 17 & 51.5 & \\
\hline Total & 21 & 63.6 & 12 & $\begin{array}{c}36 . \\
4\end{array}$ & 33 & 100.0 & \\
\hline \multicolumn{8}{|l|}{ Alkohol } \\
\hline Ya & 6 & 18.2 & 10 & $\begin{array}{c}30 . \\
3\end{array}$ & 16 & 48.5 & \multirow{3}{*}{0,002} \\
\hline Tidak & 15 & 45.5 & 2 & 6.1 & 17 & 51.5 & \\
\hline Total & 21 & 63.6 & 12 & $\begin{array}{c}36 . \\
4\end{array}$ & 33 & 21 & \\
\hline \multicolumn{8}{|c|}{ Pola makan } \\
\hline Ya & 15 & 45.5 & 1 & 3.0 & 16 & 48.5 & \multirow[b]{2}{*}{0.000} \\
\hline Tidak & 6 & 18.2 & 11 & $\begin{array}{c}33 . \\
3\end{array}$ & 17 & 51.5 & \\
\hline
\end{tabular}




\begin{tabular}{|c|c|c|c|c|c|c|c|}
\hline Total & 21 & 63.6 & 12 & $\begin{array}{c}36 . \\
4\end{array}$ & 33 & 100.0 & \\
\hline \multicolumn{8}{|c|}{ Olahraga } \\
\hline Ya & 6 & 18.2 & 10 & $\begin{array}{c}30 . \\
3\end{array}$ & 16 & 48.5 & \multirow{3}{*}{0.002} \\
\hline Tidak & 15 & 45.5 & 2 & 6.1 & 17 & 51.5 & \\
\hline Total & 21 & 63.6 & 12 & $\begin{array}{c}36 . \\
4\end{array}$ & 33 & 100.0 & \\
\hline
\end{tabular}

Sumber: Data Primer 2020

Berdasarkan analisis data menunjukkan merokok $(p=0.001)$, Alkohol $(p=0.002)$, pola makan $(p=0.000)$, olahraga $(p=0.000)$ terdapat hubungan dengan kejadian stroke. Sejalan dengan hasil penelitian Simbolon (Simbolon et al., 2018) bahwa 70,6\% penderita stroke terjadi akibat merokok dan stroke terjadi pada serangan pertama 52,9\%. Ada hubungan faktor merokok dengan kejadian stroke di Rumah Sakit Santa Elisabeth Medan. Bahwa terdapat hubungan merokok dengan kejadian stroke infark. Berdasarkan hasil penelitian diharapkan adanya peningkatan peran petugas kesehatan dalam memberikan penyuluhan kepada masyarakat tentang dampak dan bahaya rokok bagi Kesehatan (Utami, 2015). Berbeda dengan hasil penelitian (Pradipta, 2010) bahwa tidak ada hubungan yang bermakna antara kebiasaan merokok dan stroke hemoragik berdasarkan pemeriksaan CTScan kepala.

Berbeda dengan hasil penelitian (Hernawan, 2019) bahwa tidak ada hubungan yang bermakna antara kejadian stroke dan kebiasaan merokok, ada hubungan yang bermakna antara kejadian stroke dengan aktivitas fisik. Namun, tidak ada hubungan yang bermakna antara konsumsi alkohol dengan kejadian stroke. Menurut (Khairatunnisa, 2017) faktor yang tidak berhubungan bermakna dengan kejadian stroke adalah merokok, obesitas, konsumsi alkohol dan riwayat penyakit keluarga. Menurut (Maukar et al., 2014) bahwa diedukasi kepada pasien atau keluarga pasien stroke untuk mengkonsumsi makanan dengan gizi seimbang sehingga menurunkan angka kejadian stroke non hemoragik. Hasil penelitian ini menunjukkan bahwa ada hubungan yang signifikan antara tingkat konsumsi natrium dan riwayat makan dengan kejadian stroke. Tidak ada hubungan yang signifikan antara tingkat stres dengan kejadian stroke (Ramadhani \& Adrian, 2015).

Stroke merupakan penyakit neurologik yeng terjadi karena gangguan suplai darah menuju suatu bagian otak. Angka kejadian stroke meningkat seiring dengan bertambahnya usia, semakin tinggi usia seseorang semakin tinggi kemungkinan terjadi stroke. Menurut penyebabnya stroke dibagi dua yaitu stroke hemoragik akibat pecahnya pembuluh darah otak dan stroke iskemik (stroke non hemoragik) akibat adanya trombus atau embolus pada pembuluh darah otak (Wayunah \& Saefulloh, 2017). Menurut hasil penelitian bahwa pernodjo(Pernodjo Dahlan, 2011) hubungan pola makan dengan kejadian hipertensi dan ada hubungan aktivitas fisik dengan kejadian stroke.

Menuerut hasil Penelitian saraf (Saraf et al., 2014) bahwa pola makan pasien stroke paling banyak adalah pola makan buruk yaitu 46 pasien (57.5\%) dan pola makan sedang yaitu sebanyak 34 pasien (42.5\%) dari total sampel 80 pasien. Riwayat merokok pasien stroke yaitu perokok berat sebanyak 33 pasien (41.5\%), perokok ringan sebanyak 19 pasien (23.8\%) dan tidak merokok sebanyak 28 pasien (35.0\%) dari total sampel 80 pasien. Menurut cahyani(Cahyani et al., 2020)terdapat pengaruh pola makan, hipertensi dengan kejadiaan stroke di rumah sakit khusus daerah provinsi sulawesi selatan. Hasil penelitian Purwaningtiyas(Purwaningtiyas, 2014) yang menunjukkan ada hubungan yang bermakna dengan kejadian stroke usia dewasa muda adalah konsumsi makanan tinggi lemak dan 
kolesterol, aktifitas fisik, dan aktifitas olahraga. Bahwa konsumsi buah dan sayur $\geq 10$ porsi per minggu serta olahraga aerobik $\geq 3$ kali seminggu selama 30 menit menurunkan kejadian stroke iskemik berulang(Penelitian et al., 2011). Berbeda dengan hasil penelitian (Wati \& Elfira Husna, 2016) tidak ada hubungan antara kebiasaan merokok, kepatuhan diit, aktivitas fisik/ olahraga, dan kepatuhan kontrol berobat dengan kejadian stroke.

\section{Simpulan Dan Saran}

Hasil analisis peneliti tidak terdapat hubungan yang bermakna antara kepatuhan kontrol berobat dengan kejadian stroke. Pada penderita stroke yang tidak teratur melakukan kontrol berobat kejadian stroke akan meningkat dibanding dengan yang teratur melakukan kontrol berobat. Ketidakpatuhan terhadap program terapi merupakan masalah yang besar pada penderita stroke. Penderita stroke yang rutin kontrol kedokter akan terhindar dari serangan stroke. Kontrol secara teratur bertujuan untuk mendeteksi secara dini apabila terjadi peningkatan faktor resiko sehingga bisa dilakukan penanganan dan pengobatan segera. Pengobatan stroke bertujuan untuk mencegah kematian, mencegah kecacatan, mencegah dan mengobati komplikasi serta membantu pemulihan penderita stroke.

\section{Daftar Rujukan}

Alfiyanto, S., \& Muflihatin, S. K. (2018). Analisa Praktik Klinik Keperawatan pada Klien Stroke Hemoragik dengan Intervensi Inovasi Minyak Biji Bunga Matahari (Sunflower Oil) untuk Mencegah Dekubitus di Ruang Stroke Center RSUD AW Sjahranie Samarinda.

Amrina, D. A. N., \& Muflihatin, S. K. (2017). Analisis Praktik Klinik Keperawatan pada Pasien Stroke Hemoragic dengan Intervensi Latihan Lateral Prehension Grip Terhadap Peningkatan Luas Gerak Sendi (LGS) Jari Tangan di Ruang Stroke Centre AFI RSUD Abdul Wahab Sjahranie Samarinda Tahun 2017.

Cahyani, N., Hasriana, \& Anisa, N. R. (2020). Pengaruh Pola Makan Dan Hipertensi Terhadap Kejadian Penyakit Stroke Di Rumah Sakit Khusus Daerah Provinsi Sulawesi Selatan. Jurnal Ilmiah Kesehatan Diagnosis, 15(2 SE-), 117-123. http://180.178.93.169/index.php/jikd/article/view/319

Hernawan, W. (2019). Hubungan Antara Merokok, Aktifitas Fisik Dan Konsumsi Alkohol Dengan Kejadian Stroke Di Rawat Inap Rspad Gatot Soebroto Jakarta.

Khairatunnisa, K. (2017). Faktor Risiko Yang Berhubungan Dengan Kejadian Stroke Pada Pasien Di Rsu H. Sahudin Kutacane Kabupaten Aceh Tenggara. JUMANTIK (Jurnal Ilmiah Penelitian Kesehatan), 2(1), 60-70.

Maukar, M., Ismanto, A. Y., \& Kundre, R. (2014). Hubungan Pola Makan Dengan Kejadian Stroke Non Hemoragik Di Irina F Neurologi Rsup. Prof. Dr. RD Kandou Manado. Jurnal Keperawatan, 2(2).

Penelitian, A., Prawiroharjo, P., Lestari, W., \& Harris, S. (2011). Hubungan antara kebiasaan makan, merokok dan olah raga dengan kejadian stroke iskemik berulang. 28(4).

Pernodjo Dahlan, S. (2011). Hubungan Pola Makan Dengan Kejadian Stroke Di Rsud Dr. Doris Syvanus Palangka Raya. [Yogyakarta]: Universitas Gadjah Mada.

Pradipta, T. (2010). Hubungan antara kebiasaan merokok dengan stroke hemoragik berdasarkan pemeriksaan ct-scan kepala.

Purwaningtiyas, P. (2014). Hubungan Antara Gaya Hidup Dengan Kejadian Stroke Usia Dewasa Muda di RSUD dr. Moewardi Surakarta. Universitas Muhammadiyah Surakarta.

Ramadhani, P. A., \& Adrian, M. (2015). Hubungan Tingkat Stres, Asupan Natrium, dan 
Riwayat Makan dengan Kejadian Stroke. Media Gizi Indonesia, 10(2), 104-110.

Saraf, P., Dadi, R. A., Bandar, T., \& Tahun, L. (2014). Hubungan Antara Pola Makan Dan Merokok Pada Pasien Stroke Di Ruang. 1(4), 158-160.

Simbolon, P., Simbolon, N., \& Ringo, M. S. (2018). Faktor Merokok dengan Kejadian Stroke di Rumah Sakit Santa Elisabeth Medan. Jurnal Kesehatan Manarang; Vol 4 No 1 (2018): Juli 2018DO - 10.33490/Jkm.V4i1.53.

http://www.jurnal.poltekkesmamuju.ac.id/index.php/m/article/view/53

Utami, F. R. (2015). Hubungan Upaya Pencegahan Terhadap Kejadian Stroke Berulang Pada Penderita Stroke (Studi Kasus Pada Penderita Stroke Di Poli Saraf Rawat Jalan Rsd Dr. Soebandi Jember, Tahun 2014).

Wati, N. R., \& Elfira Husna. (2016). Analisis Faktor Yang Berhubungan Dengan Kejadian Stroke Pada Penderita Stroke di Ruang Rawat Inap C Lantai 1 dan 2 RSSN Bukittinggi Tahun 2016 Analysis Of Factors Related To The Stroke In Patients With Stroke In Ward C 1 st Floor And 2 nd Floor In The Rss. Jurnal Kesehatan Prima Nusantara Bukittinggi, 9(2), 169-176.

Wayunah, W., \& Saefulloh, M. (2017). Analisis Faktor Yang Berhubungan Dengan Kejadian Stroke Di Rsud Indramayu. Jurnal Pendidikan Keperawatan Indonesia, 2(2), 65. https://doi.org/10.17509/jpki.v2i2.4741 